Rev. Saúde pübl., S. Paulo

6: $317.27,1972$

\title{
THE RIGHT TO MEDICAL CARE AND ITS ECONOMIC CONSEQUENCES: AN AMERICAN DILEMMA *
}

José Duarte de ARAúJO **

RSPSP-146

ARAújo, J. D. de - The right to medical care and its economic consequences: an American dilemma. Rev. Saúde públ., S. Paulo, 6:317-27, 1972.

SUMmary: The concepts of "rights" and of "right to health care" including its evolution in modern times are discussed. The consequences of implementing this right are discussed in economic terms, regarding the situation in the United States of America. A discussion is also included on the limitations of the role of Health Insurance as a measure to solve the problem of providing health care for all individuals.

UNITERMS: Health economics*; Insurance, health *; Medical assistance *

\section{HEALTII CARE AS A RIGHT}

The first important step towards international recognition of health as a basic right of the individual was the authorization given in the Charter of the United Nations ${ }^{6}$ (Article 62), to its Economic and Social Council, to "make recommendations" regarding subjects such as "education, health and related matters". As an immediate consequence a proposition from the Brazilian and Chinese delegations was approved to call, as an urgent matter, the First International Health Conference which convened in the following year in New York, and resulted in the creation of the World Health Organization which had its constitution approved on July 22, 1946. The preamble of this constitution 8 , besides giving the widely known broad definition of health, asserted that the "enjoyment of the highest attainable standard of health is one of the fundamental rights of every human being, without distinction of race, religion, political belief, economic or social condition".

A mere definition of "rights" as "something to which one has a just claim" 27 or as "that whichs is due to anyone by law, tradition or nature" 1 does not give full extension of the real meaning of "rights" in modern society.

In western civilization the concept of human rights emerged with the Enlightenment. In Locke's writing 17 one finds the first clear statement of the individual's rights to "freedom of speech", to "worship" and to "property". The Constitution of the United States, in the XVIII century, asserted the rights of men to "life, liberty an the pursuit of happiness".

The idea that one of the main purposes of every legal government is to protect the rights of the individual against oppression suffered a serious

This paper was written at the University of California in Berkeley, while the author was under a fellowship of the World Health Organization. The ideas expressed in the article are the responsibility of the author and not of the sponsoring Organization.

** From the "Departamento de Medicina Preventiva, Faculdade de Medicina, Universidade Federal da Bahia. - Vale Unıversitário, Canela - Salvador, Bahia, Brasil". 
ARAUJO, J. D. de - The right to medical care and its economic consequences: an American dilemma. Rev. Saúde públ., S. Paulo, 6: 317-27, 1972.

blow during the second world war. As a natural reaction, when the Charter of the United Nations was drawn up, during the Conference of San Francisco, it mentioned in its preamble the specific aim of "promoting and encouraging respect of human rights" ". A special commission was created to draft international bill of human rights, and on December 10 , 1948, the General Assembly of the United Nations approved the final text of the "Universal Declaration of Human Rights" as a "common standard of achievement for all peoples and all nations" 25. This declaration represents the highest concept of "rights" and is a testimony of the goals and the values that our society professes to hold.

This Declaration was very explicit on the subject of health, saying: "Everyone has the right to a standard of living adequate for the health and well being of himself and of his family, including. medical care. .".

The most recent pronouncement to be quoted on this regard was that of the President of the United States on February 18,1971 , in a message to Congress proposing a national health strategy 28 .

President Nixon said in his message that "good health should be available to all... citizens", and he assumed the need for "equal access (to health) to all citizens for without health no man can fully utilize his other opportunities".

This summary review of important statements of health as a fundamental human right intends to show that holding this view is not an idle utopian position: much to the contrary it is a position stemming from strong and widely accepted values of our society. It seems to me that the opposite view, that of health care not being a human right, would be in opposition to the goals and values we hold to be true.

The fact cannot be denied, however, that a long distance goes between saying that health care is a right and making it effectively true.

According to the constitution of the World Health Organization 8 "governments have a responsibility for the health of their people which can be fulfilled only by the provision of adequate health and social measures". As a matter of fact the preoccupation of governments with the provision of adequate health care to its citizens traces back to the compulsory sickness insurance for industrial and other workers established in Germany by Otto von Bismarck in 1883. Two other important historical landmarks were the "Labour Code" which socialized medicine in the Soviet Union in 1922 and the "National Health Act" signed in Great Britain in 1946 establishing the National Health Service, in effective operation since 1948. In the United States the most important pieces of legislation in the direction of providing health care to the population were the Social Security Amendments of 1965 creating Medicare (Title XVIII) an Medicaid (Title XIX) 5 .

Despite these legal and institutional accomplishments the fact remains that even in the wealthiest nation in the world, the United States, a considerable sector of the population does not have access to adequate health care, and that economic barriers are the main cause of this state of affairs 20 . The situation in the poor and underdeveloped areas of the world is even more dramatic. For the purposes of this paper, however, I should limit myself to some considerations regarding the problem in the United States.

The first question to be asked is whether poverty should be a barrier to the provision of health care to all the population. The mere common sense response that this should not be the case, in the face of the vast economic resources of the country, is not sufficient. More profound and fundamental reasons 
ARAOJO, J. D. de - The right to medical care and its economic consequences: an American dilemma. Rev. Saúde públ., S. Paulo, 6: 317-27, 1972.

can and should be brought up to support the thesis that poverty should not justify lack of adequate health care.

$\mathrm{C}_{\Lambda N T O R}{ }^{4}$ examines the question from the legal standpoint. In his opinion the fact that poverty creates an inability to obtain adequate health services "constitutes an invidious discrimination within the meaning of the 14 th amendment's equal protection clause". Two Supreme Court rulings indirectly support this thesis ${ }^{12},{ }^{13}$.

Another legal approach is that of MicheLman 18 who considers that the constitutional notion of "right to life" posits on government an "affirmative obligation to furnish citizens with the minimum nevessities of life: shelter, income sufficient to procure food. and health care".

The reality remains, however, that the acceptance of the thesis that low economic status precluding access to health care imposes affirmative government obligations to remedy the de facto discrimination does not, per se, provide the health care facilities, or increased access to them, necessary to assure equal health care to all citizens.

The other question which we must answer then is, whether there are, within the political and economic system of the country, concrete measures that could be put into effect to change this situation. This may turn from a question of establishing national priorities into a more delicate matter of conflicting (or apparently conflicting) individual rights: those of the consumers vs. those of the providers of health services.

There is sufficient evidence, both from enacted and proposed legislation, and from increased public expenditures in the specific area, that the government of the United States places health care high in its list of priorities.

There seems, however, to exist a lag between the aims and the instruments used to reach them, "Medicare" contributed to the soaring increase in medical care costs 11, "Medicaid" fell short of providing adequate care for many of the poor ${ }^{24}$, and even the more recent government proposals 28,19 do not contain the mechanisms to assure the delivery of health services to all citizens, in flagrant contradiction with the stated goals.

This situation stems on one hand from an almost absolute reliance on the market as the appropriate mechanism to assure the adequate production and distribution of health services, and on the other hand from the failure of the market to perform the expected functions.

Though there are many obvious "imperfections" 15 in the market of health services to make one wonder whether it will be able to perform the functions of a free market, and though many consumers lack the sufficient income to participate in any kind of health market, there are authorities in the field that still make a strong case for the free market as the best means to improve the performance of the medical care system 14. The success of this theory depends, however, upon the occurrence of two unlikely events: the approval of health insurance legislation assuring ample coverage for all citizens and a broad reorganization of the medical care industry along a more entrepreneurial model, with emphasis on more efficient use of resources.

A review of the proposed health insurance schemes 10 shows that universal insurance, "providing assured financial support of services for the whole population" is not very likely to be forthcoming. ${ }^{2}, 3$

The much sough profound re-organization of the health services industry is a possible event, but one that would mean the transference of its leadership from 
ARAUJO, J. D. de - The right to medical care and its economic consequences: an American dilemma. Rev. Saúde públ., S. Paulo, 6: 317-27, 1972.

the physicians to other (better) entrepreneurs and also some changes in the traditional forms of doctor-patient relationship and the remuneration system. This already could be considered by some as infringing upon the "rights" of the present providers of health services.

Another approach would be the establishment of a National Health Service, patterned after the British experience 9. This, however, would be considered as an ieven greater infringency upon the rights of the providers.

In summary we seem to be dealing with a dilemma of conflicting rights and values, and that one cannot fully guarantee those of the consumers of health services without at least re-defining those of the producers in the light of the higher values of our society.

\section{ECONOMIC IMPLICATIONS OF THE CONCEPT OF MEDICAL CARE AS RIGHT}

The implementation of the idea that "access to medical care is a right" 28 will have many implications and raise many issues among which we consider the following to be the most important and worthy of discussion: financing, comprehensiveness, accessibility and quality.

\subsection{Financial implications}

Since medical services are not considered as "free goods", "adequate financial compensation to the producers or providers of these services is the first issue we have to deal with. But we must deal with this question starting from the premise that medical care should be available regardless of the individual's ability to pay 18 . That is to say that one must find appropriate mechanisms to reconcile the right of the producers to due payment, with the right of the consumers to access to the necessary services.
The principles of insurance have long since been applied to the problem in the United States with only partial success 21 . The main drawbacks of voluntary health insurance have been:

\section{a) Limitation of coverage}

Various kinds of limitations can be pointed out. One is that of policies that cover separately office services and hospital services, most commonly the latter, thereby encouraging undue use of expensive hospital services. Another is the limitation of the amount of services covered, expressed either as "deductibles" or as "cellings" for payments. There are also limitations in the quality of services covered, such as some forms of treatment, or the care of some specific diseases such as mental illness for instance. As a result of these limitations the insured person is still far from being free of the financial burden of disease, or from becoming financially dependent as a result of catastrophic illness.

\section{b) Incomplete coverage of population}

This results in part from the fact that because of a low education level some persons do not perceive the need to protect themselves and their families against the financial burden of illness. However, by far the most important cause of this phenomenon is the inability to purchase health insurance as demonstrated by the national statistics 26 showing that the percentage of insured individuals decreases as the level of income decreases. Of course, since low education level is also associated with low income, it is difficult to separate the effects of education from the lack of financial ability as the reason for not purchasing health insurance.

More recently group pre-payment plans for health services have emerged as an alternative that provide more comprehensive, more efficient and more econom- 
ARAÚJO, J. D. de - The right to medical care and its economic consequences: an American dilemma. Rev. Saúde públ., S. Paulo, 6: 317-27, 1972.

ic coverage than the traditional form of insurance 23. However, even these plans fail to solve the problem of the low income groups that cannot purchase either traditional insurance or pre-payment plans.

Since the concept of charity medicine must be discarded for both economic (rights of providers to payment) and moral (consumer's dignity) reasons, the government has been gradually charged with the responsibility to assure that the poor will get the necessary medical care. This responsibility at some time was trusted upon the County Hospitals. Later on, the federal government, through Welfare Programs, brought some much needed but still rather insufficient funds. A major thrust toward greater Federal responsibility was given by the creation of "Medicare" in 1966, assuring a form of universal health insurance for the elderly 5 .

However, "Medicaid" created at the same time, to meet the needs of the poor, failed to reach its goals, at least in part because it relied upon the willingness of the states to participate financially and to administer the programs 24 .

As a result of these efforts one witnesses a double system, or a double standard of medical services, to the disadvantage of the underprivileged, which do not get needed medical care, or get inadequate care, despite the enormous increase in government expenditures for health in the last five years ?.

A possible answer to this problem might bet the enactment of legislation creating compulsory, comprehensive health insurance. It is considered that any health insurance scheme in order to guarantee full access to medical care to every citizen should have the following characteristics:

- Universality: All persons would have to be covered regardless of ability to pay. The federal government, from tax money, would participate in the payment of the premiums according to a sliding scale for those beneath a certain level or family income (adjusted for number of dependents); the government participation would be integral payment for those in the lowest levels of income. In order to offset excessive government expenditures the legislation would provide mechanisms to assure the participation of the employers in the payment of tre premiums for those in the labor force.

- Full coverage. The insurance policy would provide ample coverage of services including preventive medicine, health maintenance, emergency care, office and laboratory services and hospitalization. Of particular importance would be coverage against catastrophic illness.

- Flexibility. The insurance mechanism would not obrigate the adherence to a single form of health delivery system. It could respect the traditional fee-for-service type of organization and the separation between office care and hospital care, but would support the tendency towards the more comprehensive pre-payment plans and specially encourage the development of new forms of medical care delivery organization such as Health Maintenance Organizations, Health Corporations, or Health Cooperatives, etc., with aims on health maintenance, comprehensiveness of services and more efficient use of manpower and facilities.

\subsection{Comprehensiveness of care}

The implications of "right to medical servces", regarding what types of services should be considered as a right, are intimately related with the financial issue that I have just discussed; however, it deserves some comments on its own.

Adequate health care presupposes a 
ARAÛJO, J. D. de - The right to medical care and its economic consequences: an American dilemma. Rev. Saúde públ., S. Paulo, 6: 317-27, 1972.

full range of services aiming at prevention of disease, early diagnosis of illness, and prompt office or hospital treatment, emergency care, and also rehabilitation. To meet the total health need of an individual it is thus essential that medical care include a comprehensive range of services, facilities and personel.

If one grants the right to one type of service, or to some types of service, while denying others, one is not really granting a right to "medical care" but only to some specific benefits, since medical care should not be fragmented. This fragmentation existis in the present system with negative results for the patients and also with a lamentable wastage of resources as a consequence.

To face this problem to kinds of measures are necessary. First, measures regarding the financing of care to avoid the limited and fragmented type of coverage so prevalent now. Second, measures tending to reorganize the delivery system in order to assure a more coordinated and more rational provision of services. Since the rights and privileges of the producers must be respected, these measures could take the indirect form of incentives, mostly financial, to the new type of delivery system. It must be said, however, that even these timid measures are bound to face opposition of the medical establishment. Perhaps this opposition will tend to decrease because the proposed changes will eventually be seen as a "lesser evil" than the much dreaded possibility of a national health service.

\subsection{Accessibility to care}

In this discussion accessibility will be taken in a material and almost geographic sense: it will mean the existence of the needed kind of services at the moment and the place the patient needs it. Since the profit oriented medical care services tend to concentrate in areas where the economic level of the population is higher, the real implications that one must confront are mainly related to how to provide acessibility to the population in the ghettos and in the rural areas. But one must also consider the problem related to the fragmentation of care that lead, even those financially able to get into the system, to be shifted from place to place because of lack of comprehensiveness of the care being provided. These two issues can be defined as assuring a ready point of entry into the system and a satisfactory range and continuity of care without unnecessary dislocations in space.

The problem of how to make adequate health care available in the underserved areas is one of the most difficult to confront. Of course, a broad health insurance program, as previously outlined, will remove most of the economic barriers. However, the problem will remain of the necessity of considerable investments to build, to equip, and to staff the new services in the now under-served areas. In other words: health insurance for everyone will not make the health services spring magically where they are most needed. Here again the government must be seen as the main source of financial incentive and support for the creation of the new facilities. Of course, at this point one should not rely entirely on federal funds but should also expect participation of the other levels of government as well as of the community.

The sparsely populated rural areas represent a special problem. There, one encounters such a low concentration of patients that can make anti-economic the provision of certain services. In addition, one must consider the particularly sensitive problem of skilled manpower: how to attract health professionals to areas lacking a great part of the amenities of the large modern urban centers? How to provide in these 
ARAUJO, J. D. de - The right to medical care and its economic consequences: an American dilemma. Rev. Saúde pribl., S. Paulo, 6: 317-27, 1972.

places the conditions for professional satisfaction and accomphishment? Here seems to be an area in which the under. lyng causes are not purely economic, and where purely economic solutions will not solve the problem.

Some countries in Latin America have addressed this problem by establishing an obligatory period of "rural medical service" for every physician. There, the medical education is almost entirely free and government supported, and it seems only a natural retribution for the education received that the physicians give some time of their career to rural practice. In the United States, however, the situation is very different since medical education is mostly paid for and supported by private funds, and there would be no grounds for government interference with one's right to choose where to work.

Another possible and perhaps more fruitful approach to the problem would be the use of para-medical personel as the primary source of health care, provided that they should have the indispensable backing up of a medical team, within reasonable distance, based either on a health center or on a community hospital. This solution would have some implications on the quality of care which is the issue that shall be discussed next.

\subsection{Quality of care}

The point of vitw that everybody should have access to the best possible medical care has very often meant for many the absence of care. If one sticks to the position that only the highest standards of medical care, compatible with the technological advances of science, are acceptable, then one natural implication is that type of care cannot be available to the whole population, everywhere at every moment, even of one were able to overcome the obvious financial difficulties.

This does not mean that the quality of care should be considered of less importance, but that there must be other criteria to judge the quality of care different from the emphasis on sophisticated technology and super-specialized personel. Of course, it must be acknowledged that efforts should be made to bring to the greatest possible number of individuals the advances of modern medical science, but whenever this proves impossible, the dilemma between the best service or no service at all must be solved by providing the kind of service that is possible, rather than by insisting on the best, and having none.

Another point, that was already mentioned, is that, there are other criteria to judge the quality of medical care, and one of them is the acceptability of the services by the consumers. This acceptability is very often determined by socio-cultural factors rather than by the technological sophistication that escapes the judgement of the average individual, especially in underserved groups.

Attention to the emotional needs of the patient, avoidance of "depersonalized" services, respect for cultural differences and of language barriers, especially for minority groups, should be considered important measures of the quality of medical care.

These new criteria for quality will be more likely put to practice if, in the new forms of health organization that are now being encouraged by the federal government, provision should be made for consumer participation.

\section{NATIONAL HEALTH INSURANCE AND THE RIGHT MEDICAL CARE}

The probable introduction of some form of National Health Insurance in the United States, in the near future, 
ARAƯJO, J. D. de - The right to medical care and its economic consequences: an American dilemma. Rev. Saúde puibl., S. Paulo, 6: 317-27, 1972.

raises many issues. Some of these issues were already dealt with in this paper. There are, however, some points and questions that deserve more detailed consideration, and these will be focused on in this section.

\section{1. "What kind of health services should be covered by national health insurance?"}

According to the point of view that, since in our society health services are among those basic goods and services deemed necessary to the pursuit of a satisfactory life, no financial barrier should impede access to needed health services, and these services should be comprehensive and non-fragmented. This amounts to saying that a national health insurance package should seek not only to remove the financial barriers but also to assure the provision to the consumers of a full range of benefits 3 including:

- Prevenitve services (health maintenance at all ages).

- Curative services (primary personal care, emergency care, specialized services, institutional services both acute and chronic, home services and rehabilitation).

The provision of preventive services, for which there is not usually a high "spontaneous" demand, aims at fostering health maintenance care, by opposition to health recuperation care. This is a measure that may pontentially lower the overall costs of health services by decreasing the necessity of use of more expensive health recuperation services.

The provision of a full range of curative services is prone to be considered a very costly measure, and this cannot be denied. But the limitation of services provided under the insurance scheme, or the limitation of the utilization of somme services by the use of "deductibles" and "co-payment" are equivalent of maintaining the financial barrier to access of adequate health care for a significant segment of the population 3 . Since we are dealing with a problem that involves allocation of scarce resources one cannot, however, simply dismiss the question of costs.

It is our contention that though no limits should be put on the proper and truly necessary use of health services, measures should be taken, and forms of control should be sought, to curb abuse and inappropriate utilization of services and facilities. One of these measures should be the more strict application of control methods already in operation suchs as Utilization Review Committees, etc.

Another possible measure would be the development of an auditing system for providers of health services under the national insurance. A third approach, and one which seems to have broad acceptance nowadays, is the encouragement by the government, through various forms of financial incentives, of the ample development of medical care organizations oriented towards the provision of "comprehensive" health services 19 . While it is disputable that these organizations will be able to lower the cost of services per se it is believed that they encourage the more rational use of services, and will lead eventually to the reduction of the overall costs.

\section{2. "How should it be financed?"}

It is sufficiently documented 22 that voluntary self insurance by the individual, either through private policies, or even as a supplement to a government sponsored benefit, will fail to achieve the goal of providing adequate health insurance coverage for the whole population. This point of view is validated by the experience with part $B$ of Medicare. 
ARAỨJO, J. D. de - The right to medical care and its economic consequences: an American dilemma. Rev. Saúde públ., S. Paulo, 6: 317-27, 1972.

Since it is not possible to rely on self insurance as an adequate means of achieving our goals, other sources of financing must be sought. The experience of Medicaid with state-sharing in a form of public assistance program discourages the reliance upon state financial participation. This leaves us with two possible sources of financing: 1) the employers and 2) the federal government. These two sources of funds could be combined in either of two ways.

A first hypothesis is through compulsory purchase by employers, through private carriers, of health insurance policies meeting the standards of adequate coverage, as defined previously in this paper, and to be set by the federal government. The financial participation of the government would be through the provision of insurance for the unemployed and possibly through sharing with the employers the cost of insurance for the employees in the lowest salary brackets. In this hypothesis no specific health tax would be necessary, and federal funds would be provided by general government revenues.

The second hypothesis is to have a true national health insurance scheme, providing full coverage, as described, to all citizens, and financed through a specific health tax. This tax would apply: a) to wages on employees and unearned income; b) to self employed earnings and c) to employers' payrolls. The percent of taxation would increase from $a$ to $c$. To keep these taxes within acceptable limits (for the tax-payer), contribution from other federal revenues would still be necessary. In this hypothesis a National Health Insurance Fund would be created, to be administered by a federal agency, with corresponding regional and local agencies, and responsible for direct payment to the providers. Further considerations on the administrative aspects are out of the scope of this paper. However, it should be said that such a scheme would make entirely unnecessary the existence of private health insurance companies 2. Pre-payment plans, health maintenance organizations, cooperatives, foundations, and similar organizations, however, would be eligible as providers, as well as individual or group practitioners.

In our opinion the second hypothesis is the one most likely to assure the elimination of a double standard of medical care, and to provide better means of effective measures toward adequate controls, aiming at cost reduction, as previously described.

\section{3. "What is the share of GNP that all expenditures for health services should cost?}

The study of health care expenditures in the last two decades shows two clear tendencies: a) towards an increase in the percentage of GNP spent in health services, climbing from $4.6 \%$ in 1950 to $6.7 \%$ in $1969 ; \mathrm{b})$ towards an increase in the percentage of total health expenditures paid by government, which climbed from $25.3 \%$ in 1950 to $37.5 \%$ in 19696 .

Forecasts of total expenditure for health services for 1974 indicate that if no health insurance is enacted, the expenditures will reach 105.4 billion dollars which will correspond to $7.8 \%$ of GNP, and that, if some form of national health insurance is enacted these expenditures would be in the range between 106,5 billion and 116,8 billion dollars, depending upon the extension of coverage in each scheme 1 . It is noteworthy that the expected increase in expenditure, even with the most comprehensive health insurance scheme, the Kennedy proposal, is only 10\% above the predicted costs if the status quo is maintained. Nevertheless there are opinions against any increase in total health expenditures, and specifically against 
ARAUJO, J. D. de - The right to medical care and its economic consequences: an American dilemma, Rev. Saúde pübl., S. Paulo, 6: 317-27, 1972.

government transfers to intermediate providers of health services, until measures are taken to improve the efficiency of the health care system and the quality of services 16 .

What seems to me very important as an additional observation on the same topic, is the fact that with the approval of a broad insurance package the percentage of the total health expenditures to be paid by the government is expected to reach $88 \%$. This figure is well beyond the $40 \%$ forecast if no similar insurance were approved. This increase in government expenditure, however would be offset by the specific taxation, and the taxpayer will be compensated by the double benefit of not having to purchase notoriously insufficient coverage through private carriers, as nowadays, and by receiving full coverage and comprehensive services through the national health insurance.

\section{4. "What restraints you might impose on the providers to prevent them from reaping "mo- nopoly" profits when instituting the national health insurance package?"}

It seems that as long as the provision of medical services in the USA will be organized as it is now, with a market oriented system, it will be impossible to deal adequately with this issue. The market of health services is full of imperfections and has many similarities with a qualified labor monopoly 15. As such it has been very difficult to be put on any form of government control. Nationalization of health services would be the only final answer to the problem, but this hypothesis is not under consideration. On the other hand, the possibilities of imposing effective controls and restraints as part of a health insurance package that maintains the market system are minimal and bound to have little if any impact on the problem.

\section{CONCLUSION}

As has been discussed, the recognition of the right to "access to medical care" for every person brings many implications, some of them rather complex and difficult to face, but none that would make impossible to implement the idea. Of course, as was repeatedly pointed in this discussion, many of the measures necessary to overcome these difficulties will depend upon government action, either legislation or financing, or both. These actions must be oriented to give full guarantee to the right of every individual to medical care regardless of his socio-economic condition. They will necessarily bring to focus the dilemma of the conflicting rights of the consumers of health services, and of the producers of these services. The solution for this dilemma, within the American economic system of free enterprise, is not an easy one. But then, no government should proclaim the right of every person to medical care, unless it is willing and prepared to take the necessary steps to make true its words.

RSPSP-146

Araújo, J. D. de - $O$ direito à assistência médica e suas consequiências economicas: um dilema americano. Rev. Saúde públ., S. Paulo, 6:317-27, 1972 .

Resumo: São discutidos os conceitos de "direito" e de "direito à saúde" incluindo sua evolução nos tempos modernos. As consequiências da implementação deste direito são debatidas em termos econômicos particularizando a situação nos Estados Unidos da América. Inclue-se também discussão das limitações do papel do sistema de Seguro de Saúde como uma medida para resolver o problema de prover assistência médica para todos os indivíduos.

UnITERmos: Assistência médica*; Economia (saúde) *; Seguro de saúde *. 
ARAUJO, J. D. de - The right to medical care and its economic consequences: an American dilemma, Rev. Saúde públ., S. Paulo, 6: 317-27, 1972.

\section{REE ER E N E S}

1 - AMERICAN Hertage Dictionary of the English Language. New York, N. Y. Dell Publishing, Co., 1970.

2 - ANALYSIS of Health Insurance Proposals Introduced in the 92nd Congress. Washington, D. C., United States Government Printing Office, 1971.

3 - BURNS, E. M. - Health insurance: not if or when, but what kind? Amer. $J$. publ. Hlth, 61:2164-75, 1971.

4-CANTOR, N. L. - The law and poor people's access to health care, Law contemp. Probl., 35: 901, 1970.

5 - CHAPMAN, C. B. \& TALMADGE, J. M. Historical and political background of federal health care legislation. Law contemp. Probl., 35: 334.47, 1970.

6 - CHARTER of the United Nations. New York, N. Y., United Nations Publications, 1945.

7 - CHILDS, A. - Introduction to medical care administration. Berkeley, Cal., University of California School of Public Health, 1970.

8 - CONSTITUTION of the World Health Organization. WHO Chronicle, $1: 29,1947$.

9 - CURRAN, W. J. - Nationalized health services: The British experience. In: PENCHANSKY, R., ed. - Health ser. vices administration, policy cases and the case method. Cambridge, Mass., Harvard University Press, 1968. p. 332.73.

10 - FALK, I. S. - National health insurance: a review of polices and proposals. Law contemp. Probl., 35: 669, 1970.

11 - GORMAN, W. - A report to the President on medical care prices. Washington, D. C., Department of Health, Education and Welfare, 1967.

12 - GRIFFIN, 1956 apud CANTOR ${ }^{4}$.

13- HARPER, 1966 apud CANTOR ${ }^{4}$.

14 - HAVIGHURST, C. C. - Health maintenance organizations and the market for health services. Law contemp. Probl., 35: 716, 1970.

15 - KESSEL, R. A. - Price discrimination in medicine. J. Law Econ., 1: 20-53, 1958.
16 - LAPMAN, R. J. - Some comments on the political and economic limits of health insurance. Bull. N. Y. Acad. Med., 45: 738_49, 1969.

17 - LOCKE, J. - Two treatises on Govem. ment, 1690. In: ENCYCLOPEDIA Britannica. London, William Bentor Publisher, 1964.

18 - MICHELMAN, F. - Forewards: on protecting the poor through the 14th amendment apud THE SUPREME Court, 1960 Term. Harv. Law Rev., 7: 83, 1969 .

19 - MYERS, B. A. - Health maintenance organizations: objectives and issues. Rockville, Md, Health Services and Mental Health Administration, 1971.

20 - POVERTY and health in the United Sta. tes: a bibliography with abstracts. New York, N. Y., Medical and Health Research Association, 1967.

21 - REED, L. S. \& CARR, W. - The benefit structure of private health insurance, 1968. Washington, D. C., U S Dept of Health Education and Welfare, 1970.

22 - ROEMER, M. et al., eds. - Health insurance plants: studies in organizational diversity. Los Angeles, University of California School of Public Health, 1970.

23 - SOMERS, A. R., ed. - The Kaiser per. manent medical care program: a sym. posium. New York, N. Y., The Com. monwealth Fund, 1971.

24 - STEVENS, R. \& STEVENS, R. - Medicaid anatomy of a dilemma. Law contemp. Probl., 35: 348, 1970.

25 - The UNIVERSAL declaration of human rights. New York, N.Y., United Nations Publications, 1948.

26 - US National Center for Health Statistics. Medical care health status and family income, United States. Washington, D.C., Us Department of Health, Education and Welfare, 1964. (Vital and Health Statistics, Serie 10, n.0 9).

27 - WEBSTER New Collegiate Dictionary. Springfield, Mass, Merrian Co., 1960. Co., 1960.

28 - WEEKLY COMPILATION OF PRESIDENTIAL DOCUMENTS, $7(8)$, Feb. 22, 1971. 